\title{
SEXUAL TRANSGRESSION FOR POWER AND IDENTITY: A GLIMPSE ON SHAKESPEARE'S TWELFTH NIGHT
}

Radha Devi Sharma (Nepal)

\begin{abstract}
Crossing social restrictions for identity and status is often the act of dissatisfying group in every society. Shakespearean society which was basically patriarchal and male-dominate set strict restrictions to impose on women's sphere. However, the suppressed women's voice sometimes denied the social restrictions in different ways as cross-dressing going beyond the boundary of women's sexuality. Cross-dressing as sexual transgression was often committed in the actual life of English Renaissance and also in the literary world for independent identity, power and authority. In this regard, this article tries to explore on the sexual transgression committed by the main female character, Viola in the play Twelfth Night to get identity and fulfill her inner desire challenging the socially prescribed norms of gender and sexuality.
\end{abstract}

KEYWORDS: Sexual transgression, power and identity, male domination, crossdressing

\section{INTRODUCTION}

Every society has certain norms on sexual orientation to control and order the bodily pleasures and behaviors of its people. Sexual transgression then is the process of moving away from the ordered and rational social state to the disordered and irrational one, often punishable by society or law. Transgression is often committed by dissatisfying groups or persons who try to cross the restrictions set by the social power structure with the desire to attain freedom and power regarding sexuality or any other aspects of life. Cross-dressing by a woman, for instance, as a socially deviant way makes her easier to enjoy the activities restricted to females.

Shakespeare's plays offer a wide range of perspectives on critical reading for generations. Reflecting, basically, on Renaissance socio-political context, many of his plays focus on the issues of gender and sexuality including its deviations. As Rampone (2011) indicates, sexuality plays a highly significant role in Shakespeare's plays and problems, because it structures gender and power relations among characters.

Though, it is often controversial that whether Shakespeare, as a representative writer of Elizabethan time, gave voice for the women suppressed within the dominant patriarchy presenting their various deviations in positive light for the betterment of their own life, or just projected the gender stereotype of men-women relationship. However, there is no doubt that he has given a wide range of women characters, many of them more intelligent, consistent and rebellious than male characters. Many of his female characters break the strictly imposed patriarchal social 


\section{Crossing the Border: International Journal of Interdisciplinary Studies}

and cultural norms to attain something of their inner interest. Deviating themselves from the social norms of gender and sexuality, either by directly forwarding their voice or consistently disobeying the patriarchy in relation to their own life, or by disguising themselves in male attire, they try to move one step beyond the patriarchy.

Shakespeare's popular comedy, Twelfth Night, involves sexual transgression committed by a female character, Viola, who disguises herself as a man called Cesario challenging the socially prescribed norms of gender and sexuality. So, this paper aims to explore the motive of cross-dressing, how it violates the norms of gender and sexuality, and what its impact on identity formation is.

\section{RENAISSANCE SOCIO-POLITICAL CONTEXT}

Shakespeare, in his writings, basically reflects the Renaissance worldview with its transitional social and political context after the medieval culture. Especially, regarding gender and sexuality and men-women relationship, Renaissance culture was male dominated, and patriarchy was strong during the 16th and 17th century. Patriarchal system assumed female's insufficiency and inferiority. As Biscetti (n.d.) points out, the patriarchal system with its assumption about female insufficiency and inferiority had been scriptural justification in the story of Eve's creation. The separation of spheres that is men as fit for public and women for private was another by-product of this alleged inferiority of women. And it had both biblical and physiological explanation for the physical, emotional and mental weakness of women. Thus, in the dichotomy of mind/body advocated by the 17th century rational philosophers, reason was associated with maleness and body with feminine. In this way, the patriarchate was quite dominating in the early modern period and women's border crossing was cautiously taken. Regarding women's confinement Howard (1988) indicates:

Women who gadded about outside the home or who talked too much...were suspected of being whores-both the open door and the open mouth signifying sexual incontinence. The good woman was closed off: silent, chaste and immured within the home. (p. 424)

Women as the feminine represented virtues such as obedience, silence, sexual chastity, piety, humility, constancy, and patience. Their relationship with men was determined with these virtues. It is not only the life but even the sexuality was determined by her confinement.

Sexuality has always been one of the most important concerns of human life throughout the history, and women's sexuality has been suffered much. Though there was some progress on women's status with Renaissance humanism and protestant reformation, still the idea that woman-kind is the weaker sex that needs to be controlled by the patriarchy was a common perception. In the early modern Europe, sexual offences such as fornication, prostitution and sodomy were handled in a variety of ways. Theoretically, men and women who were guilty of fornication were to be treated equally, but in practice, men who were found guilty of transgression were given a slight fine and required to take a vow not to engage in this behavior again where unmarried women were imprisoned, given bodily punishment and were sometimes sent away from the town where they lived even if they were pregnant as if their pregnancy should determine their treatment by the community. However, some religious reformers thought that these women should be treated more kindly (Rampone, 1988). Thus, the men-women relation was directed with the conventional 
stereotypical concept of gender and sexuality.

However, Renaissance England witnessed gradual change with some religious writings of women in the 1500s. The civil wars of 17 th century caused some social upheaval; men involved in war and political activities letting opportunities to women to take care of the household, or business and so on. And some women involved in political activities too. They refused to accept that they should undertake domestic duties and nothing more. They also demanded right to voice their political opinion, called for political rights and some dared to challenge women's exclusion from public sphere. Restoration (post-civil-war) period was one significant period of political, scientific and literary innovation, and the secularization of society of that time provided openings for women in art and writings (Wojtczak, n.d.). Due to this transitional situation, there were number of contradictions, too.

The traditional hierarchy was somehow dismantled during the revolutionary time but with several contradictions. Fissel (as cited in Biscetti, n.d.) writes, pre-war writers were more concerned with male chastity and female submission within marriage whereas post-war writers emphasize the danger of female unruly sexual behavior, no longer aggressive but potentially disruptive of social order. And restricting women's access to the public sphere was men's response to the female sexual threat. Women as emotional, fragile and easily led astray not only remained unaltered after the Restoration, but "was confirmed by the experiences of the revolutionary years" (Biscetti, n.d., p.162). However, many women from noble class became educated, observed the society's attitude towards women, their denial and control, and then women's issues became more sensitive in terms with the contemporary world view of sexuality, men-women relation and stereotyped assumption on gender. The long rule of Queen Elizabeth influenced a different perspective that women can be knowledgeable, outstanding and masculine.

Many women cross-dressed in their actual life during the Renaissance and it was considered transgressive. Howard (1988) writes:

... lower class women were pilloried and whipped and merchant wives were harangued from the pulpit for doing it because it opened a gap between the supposed reality of one's social station and sexual kind and the clothes that were to display that reality to the world. Even the state regulated dress ... especially in the urban setting preciously to keep people in their social places to which they were born. (p. 421)

So attempts to maintain social order according to different social classes or sexes was quite significant. Even the dress codes were maintained. However, these attempts were sometimes shattered with intellectual deviations from different angles as crossdressing by women to cross the system of patriarchate. Shakespeare, grasping the intellectual influence of his time uses many unconventional heroines in his several comedies including Twelfth Night.

\section{SEXUAL ADVANCEMENT OR AMBIGUITY?}

Controversies on sexuality in Shakespearean time can be seen both in the real life and in the theatre stage. Especially, cross-dressing in Elizabethan and Jacobean periods was the issue of it. Howard (1988) informs that "around 1620-James I ordered the preachers of London to inveigh from the pulpit against the practice of women dressing mannishly in the streets of London. That year also saw the publication of 


\section{Crossing the Border: International Journal of Interdisciplinary Studies}

the two polemical tracts Hic Mulier and Hace-Vir which respectively attack and defend cross-dressing" (p. 420). Such arguments definitely influenced the writings of the time. Howard further points out that it was more enthusiastically taken by the fashion-mongering wives of the city "who are accused of transgressing both class and gender boundaries. By wearing even more ornate clothing they encroached on the privileges of aristocratic women; by wearing men's clothing they encroached on the privileges of the advantaged sex" (p. 420). Reflection of the arguments based on such issues are traced in the writings of Shakespeare.

Modern critics often criticize Shakespeare saying that Shakespeare presents fluid and contradictory nature of women in the world of theatre. One reason for this contradiction is due to the convention of the boy actor in Elizabethan stage. Though women's role is presented by male actors, he gives a range of representation of women in his plays. As Prodromou (n.d.) states:

Automatically, a degree of ambiguity is introduced in presentation of masculine and feminine gender in Shakespearean comedies, histories and tragedies. The fixed, binary nature of gender ... is disrupted by the convention of boy actor and Shakespeare's dramatic use of disguise through cross-dressing. There is built-in complexity to his women, not necessarily present in the male characters, simply because they embody male and female qualities. (p. 27)

Here, the complexity of cross-dressing is sometimes intentional. This complexity is made even more complex when "the boy who played a girl then pretended to be a young man" (Prodromou, n.d., p. 27). It is found in several plays of Shakespeare. It is so in the case of Julia in the Two Gentleman of Verona, Rosalind in As You Like It, Portia in The Merchant of Venice, Imogen in Cymbeline and Viola in The Twelfth Night. This way of boy actors playing role of women and again disguising as male often make the boundary of the conventional notion of gender and sexuality blurred. The conventional order becomes threatened and subverted. Prodromou further indicates that it is not only the form of the plays that is subversive but also that what women say shakes the established patriarchal order.

Early modern England was basically patriarchal society which assumed that the women had to be controlled by the patriarchy, and maintained gender hierarchy. The practice of breaking away the strict social system by women, dressing as men was one crucial way. Howard (1998) argues that "crossdressing, as fact and as idea threatened a normative social order based upon strict principles of hierarchy and subordination of which women's subordination to men was a chief instance" (p. 418). In the dramatic world, cross-dressing was found basically by men to take women's or girl's role as women, which were not allowed to be actors on the stage. Though mostly it was men who dressed as women for the stage, but those when those boy actors acting as women or girls again cross-dressed, it was seen with reaction by many as a threat to patriarchal society.

Rampone (2011) quotes Valerie Traub's term "transvestism" instead of disguise or cross-dressing in order to describe the consequences of Rosalind's and Viola's adoptation of the masculine attire in the plays As You Like It and the Twelfth Night. As Traub indicates, transvestism indeed was a most troubling thing for the anti-theatricalists of the early modern period. Many anti-theatricalists were at once fearful and enraged by youth who dressed as women and girls thinking that they transgressed not only gender and socioeconomic borders but also erotic ones. Rampone further adds that 
current discussions focus on the idea that subversive acts are treated as a "means of exchange in a male-dominated society" (p. 149). In the Twelfth Night, cross-dressing as a subversive act of a woman character is central for both complication and resolution of the plot.

Cross-dressing makes Viola's gender identity ambiguous as she is both man and woman possessing both femininity and masculinity. Though confused, it tries to dismantle the conventional gender stereotypes and hierarchy.

\section{CROSS-DRESSING AND THE POWER EXERCISE}

Twelfth Night involves multi-layered sexual relationship and gender roles. Viola, the main female character of the play comes to the country of Illyria after a shipwreck and as a woman it is very difficult for her to sustain her life. Disguising herself as a male, she becomes a Page boy to Orsino, the Duke and a lovesick for the love of Lady Olivia who can't entertain him as she is in mourning for her brother's death. Viola, as a boy named Cesario, quickly becomes Orsino's favorite, and she finds herself falling in love with him, but difficult to pursue as a man. As Cesario is asked to deliver the Duke's love message to disdainful Olivia, Olivia herself falls in love with the young Cesario believing him a male. In this love triangle, everyone's situation is pretty miserable to fulfill his/ her desire. Olivia, however, being mistaken with Sebastian, Viola's twin brother as Cesario, marries him. But, when Cesario and the Duke come together with Olivia, the true identity is revealed. Then the Duke and Viola marry as Lady Olivia has already married to Sebestian.

The play presents a fascinating story of a female character, her sexual desire and her way of manipulating and constructing identity and power through crossdressing. Cross identification through cross-dressing or, transvestism, according to Beasley (2005), may especially refer to erotic pleasure derived from the clothing of the opposite gender, or more generally, to wish to adopt the social role of opposite gender. After being saved by the captain in the shipwreck, Viola inquires about the ruler of the country of Illyria, and when she hears "Orsino" from the captain, she immediately implants her sexual desire with him. She says, "Orsino, I have heard my father name, him:/ he was a bachelor then" (Act 1, Scene 2). This desirous reaction about Orsino indicates that she has some inner intention. As Lindhein (2007) writes, the play involves a "particular sexual and social dissatisfaction" (p. 679) as it involves cross-dressing by the main female character. It was quite controversial issue during Elizabethan and Jacobean period. It was common in theatre for boys to play women's role. Similarly, people cross-dressed to attack the boundaries of class and gender. So, though not common, it was practiced in the Shakespearean time.

Viola decides to hide herself under the mask of a man and goes to get employment by the Duke Orsino because she feels herself insecure (Amir, 2008) in a foreign land after when she is separated from her brother who is supposed to be drawn. Viola adopts male dress that is as Howard (1988) indicates "as a practical means of survival in an alien environment" (p. 431). However, this disguise is not the permanent one. In fact, as a female, in the patriarchal society, she had many obstacles to have independent identity in the public life.

Viola who has landed in an alien place feels deprived of her identity because women were confined at home and domesticity not in public space. As other women characters who disguise in Shakespeare's plays, Viola has to seek a way out from the 


\section{Crossing the Border: International Journal of Interdisciplinary Studies}

crisis. So she puts on male attire that makes her able to carry out tasks that would be never possible otherwise. She asks help from the captain to hide her true identity, "Conceal me what I am, and be my aid/ For such disguise as haply shall become/ The form of my intent..." (Act 1, Scene 2). Since she has no easy way to enter into male sphere, she has to deviate the social norms; so puts on male's costumes. Califia (as cited in Beasley, 2005) indicates that transgression of some identity norms as desire and sexuality, but may not entail transgression of outer social norms such as those regarding gender identity and conception of innate character of sexuality (p. 157). Anyway, this is a daring challenge against the social establishment and patriarchal power.

Cross-dressing might seem as a simple act on its surface as it is the way of men putting women's dress or women of men's. The most significant thing is that it is capable of changing the whole paradigm of gender and sexuality. Viola being disguised as a man has to perform every role quite in subversive way to sustain her independent manly life in a strange world. She disguises herself not only to sustain her life, rather because of her passionate desire for a person she does not know yet, she thinks, “...I can sing/ And speak to him in many sorts of music/ That will allow me very worth service" (Act 1, Scene 2). Because, she knows from the captain that the Duke has fallen sick of love of Lady Olivia who disdains him. She produces intense desire and pleasure within herself. As Foucault argues, on the one hand, sex is produced by complex interaction of discourses and power and yet contains pleasure in itself which is not the effect of any specific discourse/power exchange. On the other hand, sexuality and power are coextensive. Sexuality is always situated within the matrices of power that it is always produced and constructed within specific historical practices (Butler, 1999). It is the sense of power that inspires Viola to be Cesario, because as a female she was powerless, even not allowed to have her independent life or perform her skills and abilities. This disguise, thus, sets her in motion by intensifying her love of Orsino and also Olivia's love towards her making herself gradually more and more powerful.

The Elizabethan world view was that women were assumed as passive being or the spectators rather than active participants. But Viola challenging the established norms of the time becomes able to get the responsibility of a Page boy. Howard (1988) indicates that ".. when she adopts male dress, she proves herself masculine arena of the courtroom and to hold her own as an advocate in that arena. Her man's disguise is not a psychological refuge but a vehicle for assuming power" (p. 433). She becomes soon favorable of Orsino who sends him for the important errand of delivering his love message. Viola/Cisario tries to suggest the Duke that their plan might not work with a lady who is desperately in sorrow. Viola here tries to have her influence upon the Duke, "my noble lord,/ If she be so abandoned to her sorrow/ As it is spoke, she never will admit me" (Act 1, Scene 4). However, the Duke insists that it will work since Cesario himself is so youthful with beautiful lips and so on. But the irony is that Viola herself is in love with the Duke, "I will do my best./ To woo your lady, yet a barful strife!/ Whoever I woo, myself would be his wife" (Act 1, Scene 4).

Viola/ Cesario is quite eloquent with her disguise. The same strength of supposed manly expression and power makes Lady Olivia herself be fascinated with Viola/ Cesario. However, it creates ambiguity on Viola that she feels, "what I am, and what I would are as secret as maidenhead" (Act 1, Scene 5). In spite of this difficult situation, 


\section{SEXUAL TRANSGRESSION FOR POWER AND . .}

in her dealing with Olivia about the Duke's love, she seems quite confident and political with the use of phrases like, "most sweet lady," "Orsino's bosom" (Act 1, Scene 5), "excellently done" (Act 1, Scene 5) etc. and makes Olivia listen the Duke' s love. She says,

Nature's own sweet and cunning hand laid on:

Lady, you are the most cruelest she alive,

If you will lead these grace to the grave,

And leave the world no copy" language is like that of a man. (Act 1, Scene 5) Using the phrase "cruelest she," she distinguishes woman kind from men that women are not supposed to be so cruel hence elevating femininity as well because at end of the play she establishes her identity as a powerful woman not man. Furthermore, Cesario/ Viola uses her male way in full swing even though Olivia has already made her stand that she can't love the Duke. Viola has come to Olivia under a mission from the Duke, but her/his "acting does not provoke revulsion of being merely pretense" (Chu, n.d.). She acts much in her own free way. Viola's expressions "If I did love you in my maser's flame/ with such a suffering, such a deadly life (Act 1, Scene 5) creates an entrapment to Olivia that by the end of this scene, Olivia's grief gives way to a powerful infatuation towards not the Duke but towards Cesario. She claims herself, "I am a gentleman" (Act 1, Scene 5), to make her male identity stronger though the appearance and reality are completely different in the play.

Olivia becomes impressed with Viola/Cesario's reflection of manly power, his youthfulness, passion and beauty, i.e. "younger men are apparently more interesting to her than older nobility such as Orsino" (Amir, 2008, p. 296). On the other hand, Viola's praise of Olivia's beauty makes Olivia welcome the idea of love not for the Duke but for Voila/Cesario. Orsino- Cesario and Olivia- Cesario closeness also reflects the homoerotic attraction at the time when it was taken seriously. This attraction, in the play, dramatizes the socially constructed basis of sexuality that is determined by gender identity. The case of Viola, in different levels, is quite complex. The mutual attraction between the Duke and Cesario or between Olivia and Cesario explains both homoeroticism as well as bisexual sentiment. Especially, the disguise of Viola is for sexual freedom, and it would perhaps be completely different situation if she was only Viola not Cesario.

It supports the idea of Butler (1999) that there are no fixed identities based on the existence of genital difference. 'Coherence' and 'continuity' of identity are not logical rather socially instituted and maintained norms. If 'identity' of a subject is assured through the stabilizing concepts of sex, gender and sexuality, the very notion of the person is called into question by the cultural emergence of those 'incoherent' or 'discontinuous' gendered beings who appear to be persons but who fail to conform to the gendered norms of cultural intelligibility by which persons are defined. In the play, Cesario, as an example of cross-dressing dramatizes the gender identity which does not fit in the category of binary framework (Chu, n.d.). Viola as Cesario goes beyond the constraints of compulsory heterosexuality and binary system of feminine and masculine. So, Viola's incoherency against the presumed norms of sexuality is to be understood in different light than the traditional feminist theorists' concept of certain preexisting identity of the category of women.

The Duke, on the other hand, being fed up with, Olivia's constant rejection, criticizes women as if they are not true of their heart, 


\section{Crossing the Border: International Journal of Interdisciplinary Studies}

... no woman's heart

So big, to hold so much, they lack retention.

Alas, their love may be called appetite-

No motion of the liver, but the palate-(Act 2, Scene 4).

Viola/ Cesario, with the authority of male confidence, corrects the Duke's rude and prejudiced view of female love. She asserts that she knows, "Too well what love women to men may owe:/In faith they are as true of heart as we" (Act 1, Scene 4). She wonderfully pins a story of her own love of the Duke but making it quite ambiguous, "My father had a daughter loved a man/ As it might be, perhaps, were. I a woman" but the Duke can't draw the implied sense of it. In fact, Viola as Cesario here overpowers the Duke because the Duke himself becomes impressed by her way of expression and says, "Thou dost speak masterly" (Act 1, Scene 4). On the one hand, her expressions both with the Duke and Olivia reflect his masculine way, establish herself as a figure with perfect masculine identity on appearance; on the other hand, she finds herself in a reverse situation that she loves the Duke and is loved by Olivia, the love in both cases is difficult to pursue. Finding herself in difficult situation, at times, she curses her male costume, "Disguise, I see thou art a wickedness wherein the pregnant enemy does much!" (Act 1, Scene 1).

However, her cross-dressing has more positive influence for herself as well as others. At one level, she is recognized as a man with manly qualities both with the Duke and Olivia. Perhaps she would not get the Duke's favors, or be desired by Olivia if she was not Cesario but Viola. Her identity as a man was recognized even by Valentine at the very initial phase of Orsino-Cesario closeness. "If the duke continues these favours towards you, Cesario, you are like to be much advanced. He hath known you but three days, and already you are no stranger (Act 1, Scene 3). At another level, Viola/Cesario is able to openly make judgment of male's perception of women, "We men may say more, swear more-but indeed/ Our shows are more than will; for still we prove/Much in our vows, but little in our love" (Act 1, Scene 4). Here, she is elevating female sexuality making the Duke realize the shallowness of male perspectives. Her female awareness is already reflected when she as Cesario tries to win Olivia's love for the Duke reminding that she would be the "cruelest she" if denied the grace of love.

With cross-dressing, Viola becomes able to take initiative and control the action especially the matter of pursuing love of the Duke and manipulating the love of Olivia to her throughout the play with her masculine qualities. Her strength and courage is praised even after the revelation of her female sex even by the Duke himself.

Duke. Madam, I am most apt t'embrace your offer

[to Fiola] Your master quits you; and for your service done him,

So much against the mettle of your sex,

So far beneath your soft and tender breeding,

And since you called me master for so long,

Here is my hand-you shall from this time be

Your master's mistress. (Act 5, Scene 1)

Viola becomes the mistress of her master. Now, she returns to the domain of her real femininity. But under her masculine guise as well she never undermined femininity. She encroached on male sexuality with male attire, made strong male identity though temporary, and exercised the power of male domain, finally to prove herself as a 


\section{SEXUAL TRANSGRESSION FOR POWER AND . . .}

powerful woman. As stated by Prodromou (n. d), Shakespeare uses the device of disguise as a pretext to explore the nature of women and to subvert gender stereotypes.

Viola in the Twelfth Night, pretending to be a man demonstrates, she can do what men do quite successfully: take initiative, solve problems and in the end be a more complete woman than if she had not played the part of the Cesario. She struggles to survive as a free woman without male's protective shell. And it is the disguise that helped her to make her independent identity and exercise power.

\section{CONCLUSION}

Viola's idea of putting male attire to fulfill her desire of getting Orsino's love and to make life independent foregrounds the cultural and social construction of gender identity. When she comes to Illyria, to give way for her life and desire, she not only assumes new identity but also new gender and new pattern of sexuality. Throughout the play until the revelation of her true identity, she exercises her male way in full swing both getting favor of the man she served and being desired by a noble lady to whom also she is supposed to serve. She manipulates her power and personality and becomes able to even correct and control the masculine judgment to womankind of the man whom she desired by heart. Transgressing the social norms of gender and sexuality, she challenges the traditional concept of gender identity in terms of the binary framework. Viola overcomes a situation, quite difficult for a Renaissance woman, and establishes female identity in newer perspective dismantling the conventional assumption on gender and sexuality. She has to transgress the social order to expose the well-established and unjust power structure in the society.

Viola's transgression of the norms of gender and sexuality seems to have proved Simon de Beauvoir's famous line, 'One is not born, rather becomes a woman.' When her true sexual identity is revealed at the end, it is quite clear that her actions, performances and expressions were impressively manly under the disguise but she was not a man. This male disguise helps her to take equal role as men breaking the chain of patriarchy and allowing freedom, power and authority. She establishes her perfect male identity with her male attire, then leaving an impression of powerful female after throwing the mask.

\section{REFERENCES}

Amir, A. D. (2008). Dramatic irony in William Shakespeare's twelfth night. Journal of Missan Researches, 5(9), 289-319.

Beasley, C. (2005). Gender and sexuality. New Delhi: Sage Publications.

Biscetti, S. (n.d.). Representations of femininity in seventeenth century conduct manuals for gentlemen. Versita, 160-171. DOI: 10.2478/v10320-012-0036-3

Butler, J. (1999). Gender trouble. New York: Routledge Press.

$\mathrm{Chu}, \mathrm{H}$. (n.d). The master mistress of my passion: Cross-dressing and gender performance in twelfth night. Retrieved from http// www.sederi.org.

Howard, J. E. (1988). Crossdressing, the theatre, and gender struggle in early modern England. Shakespeare Quarterly, 39(4), 418-440.

Lindheim, N. (2007). Rethinking sexuality and class in twelfth night. University of Toronto Quarterly, 76(2), 679- 713.

Rampone. W. R. (2011). Sexuality in the age of Shakespeare. California: Greenwood. 


\title{
Crossing the Border: International Journal of Interdisciplinary Studies
}

Prodromou, L. (n.d.). Shakespeare's unruly women. APAC-ELT Journal, 26-32. Retrieved from http://www.apac.es/publications/documents/shakespeare.pdf

Shakespeare, W. (2009). Twelfth Night (J. D. Wilson Ed.) Cambridge: Cambridge University Press.

Wojtczak, H. (n.d.). British women's emancipation since the renaissance. Retrieved from http://www.historyofwomen.org

\begin{abstract}
ABOUT THE AUTHOR
Radha Devi Sharma has been working as a Lecturer of English at Tribhuvan University, Prithvi Narayan Campus, Pokhara since 24 Dec. 2007. She has received her MA in English from Tribhvuan University and MPhil in English from IACER, Kathmandu. She has published research articles on topics related to literature, culture and literary theories in various journals. Email: radhadevisharma@hotmail.com
\end{abstract}

